\title{
Effect of Instructional Leadership, Principal Efficacy, Teacher Efficacy and School Climate on Students' Academic Achievements
}

\author{
Iran Jalapang \\ School of Education and Modern Languages, \\ Universiti Utara Malaysia, Kedah, Malaysia \\ Arumugam Raman \\ School of Education and Modern Languages, \\ Universiti Utara Malaysia, Kedah, Malaysia
}

Doi: 10.36941/ajis-2020-0043

\begin{abstract}
This study is aimed to identify the influence of instructional leadership, principal's efficacy, teachers' efficacy and school climate on the academic achievement of national secondary school students in the Sri Aman Division, Sarawak. The respondents of the study consisted of 186 teachers in 7 National Secondary Schools (NSS) in Sri Aman, Sarawak. This study used a quantitative method that is a cross-sectional approach for data collection purposes. Respondents responded using a questionnaire. The SmartPLS 3.o path modelling software of the route model was used for PLS-SEM analysis. The results of the PLS-SEM analysis found that the instructional leadership of principals, efficacy of principals, efficacy of teachers and school climate have significant relationships with students' academic achievement in the 7 National Secondary Schools (NSS) in Sri Aman, Sarawak. This proves that these four variables have a strong influence on students' academic achievement and are predictors of students' academic achievement performance at national secondary schools in the Sri Aman Division. However, teachers' experience as a moderating factor was found to not affect the independent variables against the dependent variable. Finally, a comprehensive analysis on the implications of the study was carried out so that it can contribute to the scientific field of research in education.
\end{abstract}

Keywords: academic achievement, instructional leadership, principal efficacy, school climate, teacher efficacy

\section{Introduction}

There is general agreement among scholars, policy practitioners, and policy makers that school leaders are an essential contributor to improving students' performance (Fullan, 2007; Leithwood, 2005). Based on recent international empirical studies (Leithwood, Aitken \& Jantzi, 2006; Hallinger \& Heck, 1996), instructional leadership has been widely accepted as a leadership style capable of contributing to school performance and students' academic achievement. Hence, policymakers continue to prioritise the practice of worldwide leadership and leadership development in order to achieve the best outcomes in terms of sound quality education (Harris \& Jones, 2015).

In this 21st century, instructional leadership is still relevant and competitive even with competition from other leadership styles such as transformational leadership and distributed leadership (Hallinger, 2005). The Ministry of Education emphasises on the role of school leaders as instructional leaders in 
managing the change of students from pre-school to high school (Jamelaa \& Jainabee, 2011). Based on previous studies, data shows that instructional leadership can improve student academic performance by $20 \%$ (PPPM 2013-2025, KPM, 2012). Currently, education leaders should be responsible for students' performance and achievement level (Leithwood \& Fullan, 2012). The reality is that in secondary schools, principals are always required to practice productive instructional leadership tasks because they are believed to be able to contribute to students' academic achievement (Hallinger, 2011). However, in reality, principals are unable to fully practice this dimension of instructional leadership because the theory and dimensions in instructional leadership itself differ (Ginsberg, 1988; Hussein, 1993).Nevertheless, principals need to apply the functions in instructional leadership at school as they can contribute to students' academic achievement (Hallinger, 2011). The question to be asked is, can principals be reliable instructional leaders? Or are there other factors that contribute to students' achievement? This situation has persuaded the researchers to conduct this study.

\section{Literature Review}

Previous studies indicated that there is a healthy and positive relationship between instructional leadership and students' achievement (Lee Saat \& Shukri Zain, 2016; Hallinger, Hosseingholizadeh, Hashemi and Kouhsari, 2017), teacher efficacy with student achievement (Khan, Fleva, \& Qazi, 2015), and school climate with student achievement (Lai \& Han, 2018). However, researchers found no concurrent studies involving these four variables. Researchers also found that there are still fewer theories and insights that support these four consistent variables. Besides, researchers found that previous studies that put instructional leadership, principal efficacy, teacher efficacy and school climate as independent variables on students' academic achievement in the context of education in Malaysia are still insufficient, particularly studies conducted in Sarawak. Therefore, the question on whether the principal's instructional leadership factor, principal's efficacy, teachers' efficacy and school climate affect students' academic achievement remains unanswered. Since the question remains yet unanswered, further study is necessary to address the problem.

Based on the findings of previous researchers among them by Yusri and Aziz (2014) and Hou, Cui and Zhang (2019), there exists a correlation between instructional leadership of principals with students' academic achievement. James and Balasandran (2012) in their study found that instructional leadership is a directed concept of all actions and activities undertaken by principals to improve and strengthen the process of teaching and learning in schools. Hallinger and Murphy (1987) outlined instructional leadership as a principal's ability to effectively lead a school organisation with the main thrust of focusing on promoting the teaching and learning processes with the involvement of parents, teachers, students, school management, and facilities, and also in building a superior school climate. Similarly, a quantitative study conducted by Abdul Said, Jumriah and Andin (2014) indicated that principals in the Tawau district apply instructional leadership practices in performing their duties at school. Furthermore, a study by Andi Audryanah (2007) found that the efficacy of principals could influence students' academic achievement. Findings from the study show that principal's efficacy has a positive relationship with school achievement.

Similarly, a study by Kausal Punjung (2013) analysed the self-efficacy of secondary school principals and its relationship with students' achievement. He used 2 forms of instruments which are PIMRS and PSES to collect data. The findings show that principles' self-efficacy has a robust correlation with students' achievement with a score $\mathrm{r}$ of 0.63 . Lee Saat and Sukri Zain (2016) conducted a study to see the effect of principal's efficacy on students' achievement. This study was conducted using the quantitative method through questionnaires distributed to teachers in secondary school located in South Sarawak. Findings show that level principal's efficacy is high but there is no significant relationship between principal's efficacy and students' achievement.

Similarly, Hallinger, Hosseingholizadeh, Hashemi and Kouhsari (2017) studied the efficacy of principals and their impact on the commitment and efficacy of teachers in Iran. The quantitative study was conducted in elementary schools in Iran. This study found that there was a strong and 
positive relationship between the principal's efficacy and teachers' commitment.

Teachers are an important factor in determining students' success. However, previous research findings reported that teachers often lose their self-esteem or self-efficacy in the teaching and learning process, leading to weak teaching competencies (Bity Salwana, Ahmad Basri, Ramlee Mustapha \& Mohammed Sani, 2008). This situation causes the teachers' spirits to be weak and ultimately, negatively affect the effectiveness and quality of teaching and learning in the classroom. A study conducted by Khan, Fleva and Qazi (2015) on 200 government primary school teachers in India found that the level of efficacy of teachers in India was high $(M=7.25, S D=.86)$. Teachers with high efficacy demonstrate excellent performance with score $(\mathrm{M}=7.21, \mathrm{SD}=.88)$. This finding supports a study conducted by Bandura (1997) that teachers with high efficacy levels produce excellent performance and are more motivated.

Meanwhile, a random study by Aziah, Yen, and Abdul (2015) on 234 teachers was carried out using surveys and questionnaires. The results showed that the level of teacher efficacy was high with a mean score of 6.89 , but there was no significant difference between teacher efficacy based on teaching experience. A study by Mohd, Siti Noor and Nawawi (2016) on the level of relationship between teacher efficacy and students' achievement involved 375 teachers teaching in secondary schools in Bachok District, Kelantan. The findings show that the level of teacher efficacy is high.

School climate exists due to interpersonal relationships between students, families, teachers, support staff, and school administrators. Wang and Degol (2015) stated that school climate encompasses the academic, community, security, and institutional environments' dimensions and includes almost every feature of a school environment that affects people's cognitive, behavioural, and psychological development. Hersey and Blancard (1998) said that human activities can go well if the situation supports and causes the activities to take place. Hence, schools' organisation climate should be created in such a way that teachers feel comfortable in performing their task.

A conducive climate will encourage teachers to perform more optimally according to their interests and abilities. Less supportive working environments such as the bad physical environment at work and less compatible relationships between teachers do cause low work performance. A previous study conducted on school climate is by Lee and Han (2018; ) which studied the relationship between principal's leadership (Raman, Mey, Don, Daud, \& Khalid, 2015), school climate and teachers' motivation. The study was conducted in the Sri Aman District in Sarawak. The quantitative research study was conducted randomly and involved 188 respondents. The findings showed that the role of school climate is high, yet there is no significant relationship between principal's leadership and school climate. However, there is a significant relationship between school climate and teachers' teaching experience. A study by Kutsyuruba, Klinger and Hussain (2015) indicated school climate is significant to students' achievement. Although many previous studies have been conducted, there are still areas left unanswered by previous researchers. Among these areas are the effectiveness of instructional leadership, principal efficacy, teacher efficacy and school climate on students' academic achievement. This has encouraged the researchers to study the significant relationship and strength of these four variables with students' academic achievement in secondary schools in Sri Aman, Sarawak.

Based on the literature review, the following hypotheses have been established;

Har: Instructional leadership significantly affects students' academic achievement.

Ha2: Principal efficacy significantly affects students' academic achievement.

Haz: Teacher efficacy significantly affects students' academic achievement.

Ha4: School climate significantly affects students' academic achievement.

Ha5: Teacher experience is a moderator variable to the relationship between instructional leadership, principal efficacy, teacher efficacy and school climate with students' academic achievement.

\section{Method}

This study used the quantitative method through the cross-sectional approach by using questionnaires to collect data to identify the relationships between study variables (Creswell, 2014). 
The researchers chose this method because they claimed that this method is very suitable for explaining the relationships between variables and how the variables influence other variables in order to see whether such factors are predictors of a result (Gay, Mills \& Airasian, 2012). Besides, this method is used as this study emphasises on the effect of the chosen variables, thus aiming to test the theory that can be adapted to large quantities of the population (Creswell, 2009).

\subsection{Population and Sampling}

Based on data obtained from the School Management Sector of the Sarawak State Education Department on August 16, 2018, the total number of National Secondary Schools (NSS) in Sri Aman is 7 schools that are NSS Engkilili, NSS Lingga, NSS Lubok Antu, NSS Melugu, NSS Simanggang, NSS Sri Aman and NSS St Luke. The total population of secondary school teachers in Sri Aman is 538. The sampling method used by the researchers was the proportional stratification sampling approach (Creswell, 2005). The researchers used this method as it can save time and cost (Cohen, 2011), as well as taking into account the factor of sample accuracy in field studies. The teachers selected as samples in this study were the groups that represented the population studied (Creswell, 2009; Chua, 2006) and subsequently, can produce generalised results representing the entire population.

\subsection{Instrument}

The instruments used in this study consist of four sections. Section A is a questionnaire about respondents' demographics and include questions on gender, age, teaching experience and academic qualification. Section B uses the Principal Instructional Management Rating Scale (PIMRS) by Hallinger (2000) as an instrument for measuring principal's instructional leadership. Section $C$ is the Principal Sense of Efficacy Scale (PSES) instrument by Tschannen-Moran and Garies (2004) and is used to measure principal's efficacy. Meanwhile, section D is the Teacher Sense of Efficacy Scale (TSES) instrument constructed by Tschannen-Moran and Woolfolk Hoy (2001) to measure teachers' efficacy, and section E is the School Level Environment Questionnaire (SLEQ) instrument by Johnson, Steven and Zvoch (2007) used to measure school climate. For students' academic achievement, the Average School Grade (ASG) of the Sijil Pelajaran Malaysia (SPM) results in 2017 was used as the measurement instrument and was obtained from the Academic Management Sector of the Sarawak State Education Department (AMS, SSED).

\subsection{Reliability of Pilot Instrument}

Table 1 below shows the reliability of the pilot instruments based on their Cronbach's alpha $(\alpha)$ values (Urbach, Smolnik \& Riempp, 2010).

Table 1: Reliability of instrument

\begin{tabular}{lc}
\hline Instrument & Cronbach's alpha value $(\boldsymbol{\alpha})$ \\
\hline Instructional leadership & .912 \\
Principal's efficacy & .932 \\
Teachers' efficacy & .896 \\
School climate & .941 \\
\hline
\end{tabular}

\section{Findings}

\subsection{Respondent Demographics}

The respondents' demographic information was analysed using descriptive analysis. In this study, the 
respondents consisted of 186 secondary school teachers in the Sri Aman division who gave their perception and feedback on this study.

Table 2: Respondents' demographics $(n=186)$

\begin{tabular}{llcc}
\hline Background & Respondent & Number & Percentage (\%) \\
\hline Gender & Male & 85 & 45.6 \\
Age & Female & 101 & $54 \cdot 3$ \\
& 30 and below & 14 & $7 \cdot 72$ \\
& $31-40$ years & 41 & 22.0 \\
Teaching experience & $41-5$ years & 92 & 49.5 \\
& 51 years and above & 39 & 20.9 \\
& Less than 1 year & - & - \\
& $2-5$ years & 24 & 12.9 \\
Academic qualifications & $6-10$ years & 27 & 14.5 \\
& $11-15$ years & 56 & 23.1 \\
& 16 years and above & 79 & 30.1 \\
& PHD & - & - \\
& Master degree & 147 & 79.0 \\
& Bachelor degree & 39 & 20.9 \\
\hline
\end{tabular}

Table 2 above explains the background distribution of respondents of the study involving a total of 186 national secondary school teachers in Sri Aman. From the total $\mathrm{N}=186$ respondents, 85 were male respondents and this amounted to 45.6 percent of the total number of respondents. Meanwhile, 101 respondents were female teachers at 54.3 percent. For the respondents' age category, 14 respondents ( 7.72 per cent) were less than 30 years old, 41 respondents ( 22 per cent) were in the age group of 31 to 40 years old, 92 respondents (49.5 per cent) were aged between 41 and 50 years, and 39 respondents (20.9 per cent) were in the category of respondents over 51 years old. For respondents' profiles based on teaching experience, 24 respondents or 12.9 per cent have served between 2 and 5 years, 27 respondents or 14.5 per cent have served between 6 and 10 years, 56 respondents or 23.1 per cent have served between 11 and 15 years, and 79 others or 30.1 per cent have served for more than 16 years. Finally, the respondents' profile analysis based on academic qualifications showed that 39 respondents or 20.9 per cent have a bachelor's degree, 147 respondents or 79 per cent have a Master's degree, and no respondent holds a Doctor of Philosophy degree.

\subsection{Measurement Model}

Indicators for constructing the measurement model in this study are used in their reflective forms. Therefore, the researchers used the three methods as suggested by Hair, Hult, Ringle and Sarstedt (2017). Firstly, the reliability of constructs was determined through internal consistency reliability using Cronbach's alpha and composite reliability. Secondly, convergent validity was evaluated based on the value of Average Variance Extracted (AVE) and the value of outer loading (item loading), while thirdly, the discriminant validity was determined based on the value of cross-loading and Fornell-Larcker.

\subsection{Internal Reliability}

The findings show that the values of Cronbach's alpha exceeded the o.6 level and thus are accepted as in compliance with the limits proposed by Nunnally and Berstein (1994). The results on composite validity also exceeded 0.70 which is the accepted level suggested by Nunnally (1978) and Chin (1998). Table 3 below shows the values of Cronbach's alpha and composite reliability which exceeded the threshold value set for all variables. 
Table 3: Internal consistency reliability

\begin{tabular}{lcc}
\hline Construct & Cronbach's alpha & Composite reliability \\
\hline Instructional leadership & 0.742 & 0.831 \\
Principal efficacy & 0.861 & 0.897 \\
Teacher efficacy & 0.740 & 0.834 \\
School climate & 0.890 & 0.910 \\
Student academic achievement & 1.000 & 1.000 \\
\hline
\end{tabular}

\subsection{Construct validity}

The testing on construct validity should be carried out through convergent validity and discriminant validity (Hair et al., 2017). Firstly, the researchers used the repeated indicator method to obtain the convergent validity values. The requirements to be fulfilled in this method are that the composite value must exceed 0.7, the value of AVE must exceed 0.5, and the value of loading must exceed 0.7. Table 4 below shows the values for the Average Variance Extracted (AVE) are all above 0.5, the composite values all exceed 0.7, and the loading items all exceed the predetermined value of 0.7 (Fornell \& Larcker, 1981). This decision confirms that the instrument of study has met the convergent validity criteria.

Table 4: Convergent validity

\begin{tabular}{lccc}
\hline Construct & Loading & $\begin{array}{c}\text { Average Variance } \\
\text { Extracted (AVE) }\end{array}$ & $\begin{array}{c}\text { Composite } \\
\text { Reliability }\end{array}$ \\
\hline Instructional Leadership & 0.891 & 0.557 & 0.831 \\
KIP12 & 0.732 & & \\
KIP13 & 0.766 & & \\
KIP14 & 0.710 & 0.592 & \\
KIP29 & & & \\
Principal efficacy & 0.732 & & \\
EFP10 & 0.722 & & \\
EFP5 & 0.789 & & \\
EFP6 & 0.784 & & \\
EFP7 & 0.806 & & \\
EFP8 & 0.801 & & \\
EFP9 & & & \\
Teacher efficacy & 0.754 & & \\
EFG11 & 0.786 & & \\
EFG15 & 0.847 & & \\
EFG16 & 0.855 & & \\
EFG17 & & & \\
School climate & 0.741 & & \\
ISE10 & 0.716 & & \\
ISE11 & 0.712 & & \\
ISE12 & 0.726 & & \\
ISE13 & 0.710 & & \\
ISE5 & 0.763 & & \\
ISE6 & 0.784 & & \\
ISE7 & 0.827 & & \\
ISE8 & 0.782 & & \\
ISE9 & & & \\
Student academic achievemeoo & \\
\hline & & & \\
\hline
\end{tabular}

Secondly, according to Fornell and Larcker (1981), discrimination validity can be fulfilled if the square root of the AVE is higher than the cross-correlation value of the latent variable. Therefore, according 
to the recommendations (Fornell \& Larcker, 1981), Table 5 below shows the results of the study which show that the square root of AVE is higher than the correlation value between the latent variables. This finding confirms that the study instrument meets the discrimination validity criteria with crossloading values.

Table 5: Discriminant validity (Fornel \& Larker criterion)

\begin{tabular}{ccccc}
\hline & EFG & EFP & ISE & KIP \\
\hline EFG & $\mathbf{0 . 7 5 4}$ & & & \\
EFP & 0.081 & $\mathbf{0 . 7 1 6}$ & & \\
ISE & 0.116 & 0.112 & $\mathbf{0 . 7 2 8}$ & \\
KIP & 0.257 & 0.128 & 0.091 & $\mathbf{0 . 7 4 6}$ \\
\hline Note: & EFG=Teacher Efficacy, & EFP=Principal & Efficacy, & ISE=School climate, \\
KIP=Instructional Leadership & & & &
\end{tabular}

\subsection{Structural Model}

The Partial Least Squares (PLS-SEM) path modelling using SmartPLS 3.0 application package (Ringle, Wende \& Becker, 2015) was used for hypothesis testing (table 6). For hypothesis 1, the relationship between principal's instructional leadership and students' academic achievement was found to be significant $(~(=0.782, t=1.819, \mathrm{p}<0.05)$. Hence, hypothesis 1 is supported. For hypothesis 2 , the results show that they relationship between principal's efficacy and students' academic achievement is also significant $(ß=-0.513, t=2.162, p<0.05)$, hence hypothesis 2 is supported. For hypothesis 3 , the relationship between teacher efficacy and student achievement was found to be significant $(~(=0.178, t=3.089, p<0.05)$, thus hypothesis 3 is supported. For hypothesis prediction 4 , the correlation between school climate and students' academic achievement was found to be significant ( $\beta=-$ $0.496, t=1.192, p<0.05$ ), so hypothesis 4 is supported. Table 6 below shows the results of all the hypotheses. Meanwhile, before analysing the structural model using PLS-SEM, the prerequisite that needed to be evaluated was the values of $R^{2}$ for each dependent variable (endogenous) as the predictive power of the structural model. Thus, the $\mathrm{R}^{2}$ value of the dependent variable (endogenous) academic achievement is o.113. According to Falk and Miller (1992), the value is at the minimum required of at least 0.100 .

Table 6: Path analysis and hypothesis testing

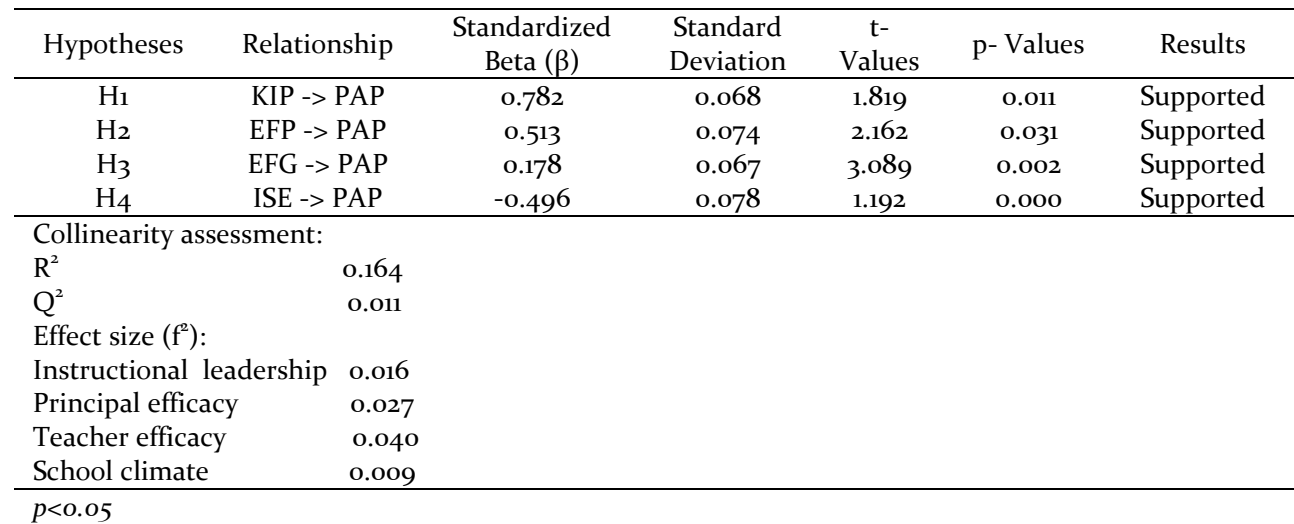




\subsection{Effects of Teacher Experience as Moderator (Peng*) $\left(\mathrm{H}_{5}\right)$}

The product indicator approach was used to estimate the effect of teacher experience as a moderator (Peng*) on the relationship between the independent variables and the dependent variable. The $\mathrm{H}_{5}$ hypothesis consists of $\mathrm{H}_{5} \mathrm{a}, \mathrm{H}_{5} b, \mathrm{H}_{5}$, and $\mathrm{H}_{5}$ d. Table 7 shows the effects of teacher experience as moderator (Peng*).

Table 7: Effect of teacher experience as moderator (Peng*)

\begin{tabular}{ccccccc}
\hline $\mathrm{H}_{5}$ & Relationship & $\begin{array}{c}\text { Standardized } \\
\text { Beta }(\beta)\end{array}$ & Standard Deviation & t-Value & p-Value & Results \\
\hline $\mathrm{H}_{5}$ & Peng*KIP -> PAP & -0.046 & 0.089 & 1.251 & 0.802 & Rejected \\
$\mathrm{H}_{5}$ & Peng*EFP -> PAP & 0.103 & 0.133 & 0.753 & 0.452 & Rejected \\
$\mathrm{H}_{5}$ & Peng ${ }^{*}$ EFG -> PAP & -0.023 & 0.081 & 1.105 & 0.270 & Rejected \\
$\mathrm{H}_{5 d}$ & Peng*ISE -> PAP & 0.113 & 0.113 & 0.716 & 0.474 & Rejected
\end{tabular}

Note: $\mathrm{EFG}=$ Teacher efficacy, EFP=principal efficacy, ISE=School climate, KIP=Instructional leadership

Based on Table 7 above, the results of this test show that teacher experience as moderator (Peng*) does not have significance on the relationship between the independent variables and the dependent variable. This causes all $\mathrm{H}_{5} \mathrm{a}, \mathrm{H}_{5} \mathrm{~b}, \mathrm{H}_{5}$, and $\mathrm{H}_{5}$ d hypotheses to be rejected. Therefore, these results indicate that teacher experience (Peng ${ }^{*}$ ) as a moderator does not have an impact on the relationship between instructional leadership, principal's efficacy, teachers' efficacy and school climate on students' academic achievement.

\section{Discussion}

This study aims to identify the influence of instructional leadership, principal's efficacy, teachers' efficacy and school climate on students' academic achievement. The results show that there is a significant relationship between principal's instructional leadership, principal's efficacy, teachers' efficacy and school climate on students' academic achievement. This finding is in line with the hypotheses of the study.

Previous research have proven significant correlations between principal's instructional leadership with students' academic achievement such as results in studies by Azlin, Jamalullail, Satar and Norhayati (2013), Norashikin, Ramli and Nurnazahiah (2013) and Hou, Cui and Zhang (2019). Besides, this decision is also supported by Ramli Basri, Norashikin Abu Bakar and Foo (2017) whose study was conducted on 387 secondary school teachers in Johor. The results showed that there was a significant positive correlation between principal's instructional leadership and students' academic achievement with an $\mathrm{r}$ value of 0.245 and sig $=0.000(\mathrm{p}<0.05)$. This finding explains that if princiapls' instructional leadership increases, students' academic achievement will also increase. Although the outcome does not show a strong correlation between principal's instructional leadership and students' academic achievement, instructional leadership must still be given particular attention as the masters have confirmed the importance of instructional leadership in improving students' academic achievement at school (Hallinger, 2011).

The findings are similar to results of a study conducted by Andi Audryanah (2007) which reported a significant relationship between principal's instructional leadership and schools' academic achievement, although the level of correlation shown was relatively low. Meanwhile, Quah's (2011) study on instructional leadership in Malaysia also demonstrated an alignment between instructional leadership practices and student academic achievement. This proves that the role of instructional leadership is very important in improving the academic achievement of students in schools. Hence, for the significant results on the relationship between principal's efficacy and students' academic 
achievement is supported by Kausal Punjung (2013) in his studies on the Tawau district and the findings of Hallinger, Hosseingholizadeh, Hashemi and Kouhsari's (2017) study on 111 principals and 345 primary school teachers in Iran which results show that there is a significant relationship between principal's efficacy and students' academic achievement.

Furthermore, for the significant results of the relationship between teachers' efficacy and students' academic achievement, this finding is consistent with studies conducted by Gibson and Dembo (1984) and Tschannen-Moran and Hoy (2001) which results show that there is a significant relationship between the level of teacher efficacy and students' achievement. Teachers' dedication refers to the teachers' efficacy construct (Bandura, 1997). Teachers with high efficacy impose great experience in mastery skills compared to teachers with low efficacy as they tend to neglect students' cognitive development and abilities (Gibson \& Dembo, 1984). A high level of efficacy encourages teachers to make more effort in their teaching tasks. Finally, for the significant results for the relationship between school climate and students' academic achievement, this decision is in line with a study conducted by Suhaili Mohd Yusoff and Khaliza Saidin (2016) involving 248 teachers of secondary schools located in Machang, Kelantan. The findings show that there is a significant and positive relationship between school climate with students' academic achievement.

\section{Conclusion}

Overall, based on the results of the study, instructional leadership, principal's efficacy, teachers' efficacy and school climate were at high levels. The findings also show that there is a significant relationship between instructional leadership, principal's efficacy, teachers' efficacy and school climate with students' academic achievement. In summary, this study clearly shows that instructional leadership, principal's efficacy, teachers' efficacy and school climate have a very strong influence on students' academic achievement. Hopefully the Ministry of Education, the State Education Department, the District Education Office and schools will provide the best opportunities for students to further develop and improve their academic results. School management should take the initiative to provide a superior school climate and culture as well as collaborate with parents' and teachers' associations to create better schools.

This study employed four constructs to measure factors that influence students' academic achievement. Therefore, the answers to each study hypothesis in this research can contribute to the field of knowledge related to the four constructs. Moreover, the researcher also examined the effects of teachers' experience as moderators; however, it did not have a significant impact on the study's constructs.

The results of this study contribute to knowledge that can be referred to by educators or education leaders in Malaysia as a guide to improving students' academic performance. This study provides input for the Aminuddin Baki Institute (IAB) as the training centre for the field of management, and education leaders from the Ministry of Education Malaysia. Besides, the findings of this study allow IAB to coordinate, review, reorganise and formulate new course modules related to the leadership and development of principals and teachers in schools. Further studies need to be carried out as this study focuses only on teachers as respondents. This situation can lead to a biased assessment by teachers. Future researchers can modify these instruments by involving principals and parents as appraisers or respondents to address the problem of bias.

\section{References}

Abdul Said, A., Jumariah, A. A., \& Andin, C. (2014). Relationship instructional leadership headmaster to the commitment and job satisfaction in primary school. Paper Presented at The International Conference on Education. Sabah, Malaysia.

Abu Bakar, N., Basri, R., \& Abas, N. (2013). Principal instructional leadership and teacher leadership. Postgraduate Seminar in Education, UPM, Malaysia. 
Abu Bakar, N., Basri, R., \& Foo, S.F. (2017). The relationship between teacher leadership to student academic achievement. International Journal of Education and Training (InjET) 1(2) 1- 11.

Andi, A. M. N. (2007). Instructional leadership and self-efficacy of high school principals and their relationship to school academic achievement. (Unpublished master's theses). Universiti Teknologi Malaysia, Malaysia.

Ang, J. J. S., \& Balasandran, R. (2009). Instructional leadership: A practical guide. Kuala Lumpur: PTS Professional.

Awanis Mohd, Ainunmadiah Mohd Nawawi., \& Siti Noor Ismail. (2016). Proceeding of ICECRS, 1, 312- 326. doi: http://dx.doi.org/10.21070/picecrs.v1i1.500

Aziah, I., Yen, L. H., \& Abdul Ghani, K. A. (2015). Professional learning community and teacher self-efficacy of secondary teachers in Penang. Journal of Educational Leadership, 2,1-12.

Azlin, Norhaini Mansor, Jamalullail, Abdul Wahab Rasul., \& Norhayati (2013). Principal leadership activities in Southeast Asia: TIMSS data analysis 2011. Proceedings of the National Education Management and Leadership Seminar,183-193.

Bandura, A. (1997). Self-efficacy, the exercise of control. New York, NY: W.H Freeman Company.

Bity Salwana Alias, Ahmad Basri Md.Yusoff, Ramlee Mustapha., \& Mohammed Sani Ibrahim, (20o8). Competency of Malaysian secondary school principals in curriculum management. 15th National Seminar on Educational Management and Leadership Seminar paper, IAB, Genting Highland.

Chua, Y. P. (2006). Basics of Research Statistics: Methods and Statistics of Research: Book 1. Kuala Lumpur, Malaysia: McGraw Hill.

Cohen, L., Manion, L., \& Morrison, K. (2011). Research methods in education (7th Ed). London: Routledge, Taylor \& Francis Group.

Creswell, J. W. (2005). Educational research: Planning, conducting, and evaluating quantitative and qualitative research (4th ed.) New Jersey, USA: Pearson Merill Prentrice Hall.

Creswell, J. W. (2009). Research design: qualitative, quantitative and mixed methods approaches ( $3^{\text {th }}$ ed.) London, USA: SAGE Publications Inc.

Creswell, J. W. (2014). Educational research: Planning, conducting and evaluating quantitative and qualitative research ( $4^{\text {th }}$ ed.) USA: Pearson Education, Inc.

Falk, R. F., \& Miller, N. B. (1992). A primer for soft modeling. Akron, OH, US: University of Akron Press.

Fornell, C., \& Larcker, D. F. (1981). Structural equation models with unobservable variables and measurement error. Journal of Marketing Research, 18 (1), 39-50.

Gay, L. R., Mills, G. E., \& Airasian, P. (2012). Educational research: Competencies for analysis and applications (10 ${ }^{\text {th }}$ ed.). Boston, USA: Pearson.

Gibson, S., \& Dembo, M. H. (1984). Teacher efficacy: A construct validation. Journal of Educational Psychology, 76 (4), 569-582.

Ginsberg, R. (1988). Worthy goal, unlikely reality: The principal as instructional leader. NASSP Bulletin, 72 (507), 76-82.

Hair, J. F., Hult, G. T. M., Ringle, C. M., \& Sarstedt, M. (2017). A Primer on Partial Least Squares Structural Equation Modeling. (2th Ed). Thousand Oaks: Sage.

Hallinger, P. (2000). A review of the principal instructional two decades of research on the principalship using management rating scale. Retrieved from http://www.leadingware.com

Hallinger, P. (2005). Instructional leadership and the school principal: A passing fancy that refuses to fade away. Leadership and Policy in Schools, 4(3), 221-239. doi:10.1080/15700760500244793

Hallinger, P. (2011). A Review of three decades of doctoral studies using the principal instructional management rating scale: A lens on methodological progress in educational leadership. Educational Administration Quarterly, 47(2), 271-306.

Hallinger, P., \& Murphy, J. (1987). Assessing and developing principal instructional leadership. Journal of Educational Leadership, 45(1), 54-62.

Hallinger, P., Hosseingholizadeh, R., Hashemi, N., \& Kouhsari, M., (2017). Do beliefs make a difference? Exploring how principal self-efficacy and instructional leadership impact teacher efficacy and commitment in Iran. Educational Management Administration E Leadership. 46 (5) 80o-819. doi.org/10.1177/1741143217700283.

Harris, A., \& Jones, M. S. (2015). Leading futures: Global perspectives on educational leadership. London, U. K.: Sage Publications.

Hersey, P., \& Blanchard, K. (1988). Management of organizational behavior: Utilizing human resources (5th ed.). Englewood Cliffs, NJ: Prentice-Hall.

Hou, Y., Cui, Y., \& Zhang, D. (2019). Impact of instructional leadership on high school student academic achievement in China. Asia Pacific Education Review. doi:10.1007/s12564-019-09574-4.

Hussien Mahmood. (1993). School leadership and effectiveness. Kuala Lumpur: Dewan Bahasa dan Pustaka. 
Jamelaa, A., \& Jainabee, M. (2011). Instructional leadership and attitude towards organizational change among secondary schools principal in Pahang, Malaysia. Procedia-Social and Behavioral Sciences, 15, 3304-3309.

Johnson, B., Steven, J.J., \& Zvoch, K. (2007). Teacher's perception of school climate: A validity study of scores from the revised school level environment questionnaire. Education and Psychological Measurement, 67. 833-850.

Khan, A., Fleva, E., \& Qazi, T. (2015). Role of self-esteem and general self-efficacy in teachers' efficacy in primary schools. Psychology, 6, 117-125.

Kutsyuruba, B., Klinger, D. A., \& Hussain, A. (2015). Relationships among school climate, school safety, and student achievement and well-being: A review of the literature. Review of Education, 3(2), 103-135.

Lai, E. E. F., \& Han, C. G. K. (2018). The relationship between principal leadership and school climate with teacher motivation. Malaysian Journal of Social Sciences and Humanities (MJ - SSH), 3(2), 1-16.

Lee Saat., \& Sukri Zain. (2016). Influence of instructional leadership, effectiveness and routine tasks of principals on academic achievement. Journal of Social Sciences and Humanities 1(3), 42-65.

Leithwood, K., \& Fullan, M. (2012). $21^{\text {st }}$ Century Leadership: Looking Forward. 4 (1) 1-22.Retrievedfrom http://www.edu.gov.on.ca/eng/policyfunding/leadership/fall2o12.pdf

Leithwood, K., Aitken, R., \& Jantzi, D. (2006). Making school smarter: Leading with the evidence (3 ${ }^{\text {th }}$ ed.). California, USA: Sage Publications.

Nunnally, J. C., \& Bernstein, I. H. (1994). Psychometric theory (3th ed.). New York, USA: McGraw-Hill.

Nunnally, J.C. (1978). Psyochometric theory (2nd. Ed.), New York: McGraw-Hill

Malaysian Education Blueprint, MEB: 2013-2025. (2012). Ministry of Education. Retrieved from http://www.moe.gov.my/v/pelan-pembangunan-pendidikan-malaysia-2013-2025.

Punjung, K. (2013). Instructional leadership and self-efficacy of school principals. (Unpublished master's theses, Universiti Malaysia Sabah). Retrieved from http://eprints.ums.edu.my/id/eprint/18733

Raman, A., Mey, C. H., Don, Y., Daud, Y., \& Khalid, R. (2015). Relationship between Principals' Transformational Leadership Style and Secondary School Teachers' Commitment. Asian Social Science, 11(15). doi:10.5539/ass.v11n15p221

Quah, C.S. (2011). Instructional leadership among principals of secondary schools in Malaysia. International Research Journals, 2(12), 1784-180o. Retrieved from http://www.coe.ohio.state.edu/ahoy/AERAEfficacymeasure\%20.pdf.

Ringle, C. M., Wende, S., \& Becker, J.M. (2015). SmartPLS 3. Bonningstedt: SmartPLS.

Academic Management Sector (2018). Sarawak State Department of Education. Malaysia Education Ministry.

Suhaili Mohd Yusof., \& Khaliza Saidin. (2016). Proceeding of ICECRS, 1,635-646. International Seminar on Generating Knowledge Through Research, UUM-UMSIDA. Sintok, Kedah, Malaysia.

Tschannen-Moran, M., \& Hoy, A. W. (2001). Teacher efficacy: Capturing an elusive construct. Teaching and Teacher Education, 17: 783-805.

Tschannen-Moran, M., \& Gareis, C. (2004). Principals' sense of efficacy. Journal of Educational Administration, 42, (5) 573-585. doi.org/10.1108/09578230410554070

Urbach, N., \& Ahlemann, F. (2010). Structural equation modeling in information systems research using partial least squares. Journal Of Information Technology Theory And Application, 11(2), 5-40. doi.Org/10.1037/oo219010.90.4.710

Wang, M. T., \& Degol, J. L. (2015). School climate: A review of the construct, measurement, and impact on student outcomes. Educational Psychology Review, 1-38. 